\title{
A Tuffier-fisztula késői következményeinek mútéti megoldása
}

\author{
Hajdú Erzsébet dr., Bajory Zoltán dr., Fehér Ádám dr., Pajor László dr.
}

\begin{abstract}
ÖSSZEFOGLALÁS
Célkitűzés: A szerzők egy régi, már elfelejtett műtéti típus, a Tuffier-fisztula késői következményeiről számolnak be.

Esetismertetés: A 44 éves nőbeteg pseudohermaphroditismus masculinus és urethra, vagina atresiával született. A hólyag és az uterus bicornis a végbél felé sipolyt képzett. Még újszülöttkorban a péniszszerű clitorist reszekálták, a sipolyt a Tuffier-elvnek megfelelően kiszélesítették, így a vizelet és széklet keverten ürült a hólyagból, a kontinenciát biztosító anus nyiláson keresztül. 1991-ben coloplasztikus vaginapótlás történt. 2013-ban, 41 éves korában jelentkezett először klinikánkon azotaemiával, rendszeres lázas epizódokkal, amely hasi fájdalmakkal, puffadással társult. MR-vizsgálat megerősítette, hogy a vizelet a zsugorodott hólyagból a végbélbe folyik, a bal vese pedig kisebb, zsugorodott lett, de pangás egyik vesében sem alakult ki. 2013-ban először az urétereket izolált bélszakaszba ültettük, azaz Bricker-hólyagot készítettünk, így a széklet-vizelet-elválasztás megtörtént, a $200 \mu$ mol/liter körüli kreatininszint felére csökkent, a puffadás megszünt. Kontroll MR-vizsgálatnál a vastagbél tágulata csökkent, a Tuffier-fisztula jelenlétét a zsugorhólyagban és a méh ürterében lévő gázbuborék igazolta. 2014-ben az uterust és a hólyagot eltávolítottuk, a sipolyt a bél felé lezártuk, így a béltartalom ürülése ide megszűnt és a lázas epizódok sem ismétlődtek. Az azotaemia lassúbb ütemben ugyan, de tovább romlott.
\end{abstract}

Megbeszélés: A Tuffier-sipoly készítése régi, elavult mútét, késői következményei elöre láthatók. Ezek megszüntetése bonyolult mütéti sorozattal lehetséges, ez pedig kihivást jelent a kezelőorvosoknak.

\section{KULCSSZAVAK:}

URETHRA ATRESIA, VAGINA ATRESIA, TUFFIER-FISZTULA, URETERO-ILEO-CUTANEOSTOMIA

\section{Operative solution of late consequences of the Tuffier fistula}

\section{SUMMARY}

Objective: The authors present a case history of the late complications of an obsolote, nearly unforgotten surgical operation method, the Tuffier fistula procedure.

Case report: The 41-year-old woman was born with congenital urogynecological malformations, pseudohermaphroditism, atresia of vagina and urethra. The penis-like clitoris was resected in early childhood and the fistula artificially widened between the bladder and rectum with Tuffier method. The mixture of urine and faces was passed through anal sphincter and this secured the continence. In 1991 a coloplastic vaginal substitution was performed without connection with the uterus. She was admitted to the Department of Urology as an adult for febrile episodes, abdominal pain - especially during menstruation - and elevation of serum creatinine level. The MR scan revealed a shrunken left kidney, communication between the uterus, the small bladder and the rectum. In 2013 a Brickerbladder was created and this operation decreased temporarily the creatinine level, but through the persistant Tuffier fistula faces was passed into the uterine cavity. At a second session, the bladder remnant and the uterus were removed and the fistula closed. This intervention stopped the febrile episodes and the painful menstruation.

Conclusion: The Tuffier fistula procedure now is an obsolete surgical method with predictable late consequences. The remodelling of these is a surgical challenge, needs complex and multiple surgical operations in most cases.

\section{KEYWORDS:}

URETHRAL ATRESIA, VAGINAL ATRESIA, TUFFIER FISTULA, URETERO-ILEO-CUTANEOSTOMY 


\section{Bevezetés}

Előfordul, hogy a régi, már elfelejtett mútéti típusok késői következményeivel találkoznak az urológusok. A Tuffier-fisztula történelmi mútét, a megoldást a szerző 1892-ben javasolta és 1894-ben a prágai Maydl már 97 esetból 71 gyógyulásáról számolt be (3). A mútét lényege, hogy hólyagnyak-betegségnél - szúkület vagy záróizom-hibában - mesterséges sipolyt képeznek a hólyag hátsó és a rectum mellső fala között. A szerző és alkalmazó előnyösnek vélte, hogy a kontinenciát a végbélzáróizom biztosítja, és a refluxot a vesico-ureterális „sphincter" meggátolja. Előnyt jelentett az is, hogy az urétert nem kell a bélbe ültetni, így az uretero-intesztinális szúkület veszélye nem áll fenn, valamint a mútét infraperitoneálisan elvégezhető; ez döntő szempont volt az antibiotikum-korszak előtt. A huszadik század végére már jelentősen csökkent azon betegek köre, ahol egyáltalán szóba jöhetett ez a megoldás. Szücs és Keszthelyi közleményéből is tudjuk, hogy a székletvizelet-keveredés és a bélben uralkodó magas nyomás mindenképpen fertőzés és károsodás veszélyét jelenti a vesékre (2). Magyarországon az uretero-sigmoidostomia, illetve annak módosítása egészen a kilencvenes évekig a vizeletelterelés alapmútéte maradt, így a széklet-vizelet-keveredés következményeiről, a fertőzésről, az acidózisról és az éjszakai anális inkontinenciáról jelentős klinikai tapasztalat halmozódott fel (1). Tuffier-fisztulával operált esetünket nem a követési idő, hanem a beavatkozás szövődményei miatt tartottuk közlésre érdemesnek.

\section{Esetismertetés}

Cz. M. 1972-ben született kombinált rendellenességgel, ezt pseudohermaphroditismus masculinusnak itélték. Sem vagina, sem húgycső nem fejlödött ki, a hólyag egy járattal összenyílt a végbéllel, így cloakaként müködött. 1972-ben a nagyobb, péniszszerü clitorist reszekálták az akkori idők módszere szerint. Ez egyszerü reszekció volt, nem történt meg a mai elvek alapján a glans és a benne futó idegek kimélése, hiszen most már közismert ezek szerepe az orgazmus létrejöttében. A hólyag azonban a vékony sipolyon át nehezen ürült, igy 1975 áprilisában mütéttel epicystostomát létesítettek, amelyen át az elfolyás megoldódott. Még ez év júniusában Tuffier-fisztula készült, azaz a meglévő hólyagsipolyt a végbél felé megtágították és ezzel egy ülésben az epicystostomát zárták. Már ekkor - 41 éve - észlelték, hogy a bal vese kisebb, a jobb pedig kompenzatorikusan megnagyobbodott. Ezt a zsugorvesét, amelyben pangás nem mutatkozott, kár lett volna eltávolítani, mert ez is hozzájárult a renalis egyensúly fenntartásához. 1991-ben, mikor a beteg 19 éves volt, vastagbélből vaginát képeztek, átmeneti biztonsági kétnyílásos colostomával, ezt fél év múlva zárták. A képzett hüvely alkalmas volt nemi életre, igaz, ehhez rendszeres tágítás kellett. Ez a mesterséges vagina persze nem került összeköttetésbe az osztott üregü méhvel, igy a menstruáció mindig fájdalmat okozott, a váladék a hólyagba, illetve a végbélbe jutott és a széklet-vizelet-keverékkel távozott. A Tuffier-fisztula készitését követő 40 évben rendszeresen jelentkeztek, lázas állapotok, alhasi- és vesetáji fájdalommal kisérten ezt pyelonephritissel magyarázták és a legkülönfélébb antibiotikummal gyógyították. Lassan, de folyamatosan emelkedett a kreatininszint, 2012-ben 200 umol/l körüli értéket mértek, ezt acidózis kisérte.

2013-ban került felvételre Klinikánkra hasi feszülés, puffadás, egyre gyakoribb lázas periódusok, magas vérnyomás miatt. A panaszok mértéke miatt a beteg megoldást szorgalmazott, de a mütétet bonyolultsága miatt senki sem vállalta. Az UH- és MR-vizsgálat szerint a vesékben kevés pangás látszott, a bal vese 7, a jobb $13 \mathrm{~cm}$-esnek bizonyult, a tágult belekben folyadék - vizelet - pangott, a fisztula kirajzolódott (1. ábra). Először a felszálló fertőzés forrását kívántuk megszüntetni, ezért előkészités után 2013-ban uretero-ileocutaneostomát (Bricker-hólyag) készitettünk. A kiterjedt hasi mütéteknél abban az időben rutinszerüen appendectomiát is végeztünk, amelynek szövettana endometriózist mutatott. A hasi feszülés, és a belek tágulata megszünt, a vizelet a sztómán keresztül szabadon ürült, a kreatininszint megfeleződött. Sajnos az időnként jelentkező alhasi fájdalmak, lázas periódusok megmaradtak, hiszen a Tuffier-fisztulán keresztül a széklet az inaktív és zsugorodott hólyagba jutott és fertőzést okozott. Közben a me-

\section{1. ÁBRA: MR-FELVÉTEL A KISMEDENCÉRŐL, GÁZBUBORÉ- KOK A FÉLHOLD ALAKÚ ZÖLD NYÍLLAL JELÖLT ZSUGORHÓ- LYAGBAN, ÉS SÁRGA NYÍL MUTATJA A SIPOLYJÁRATOT}

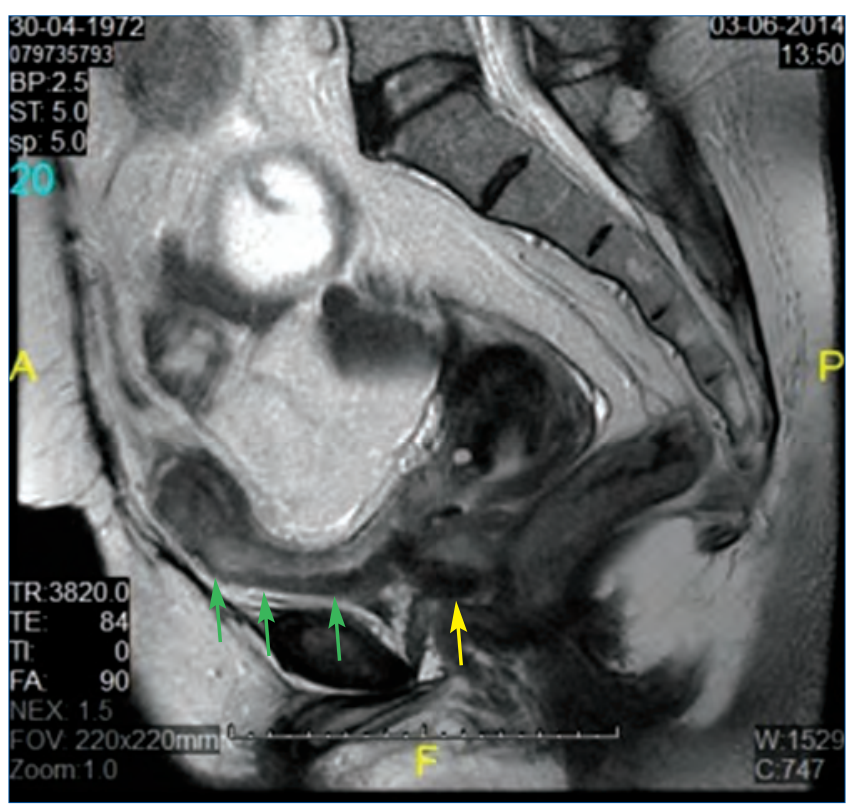




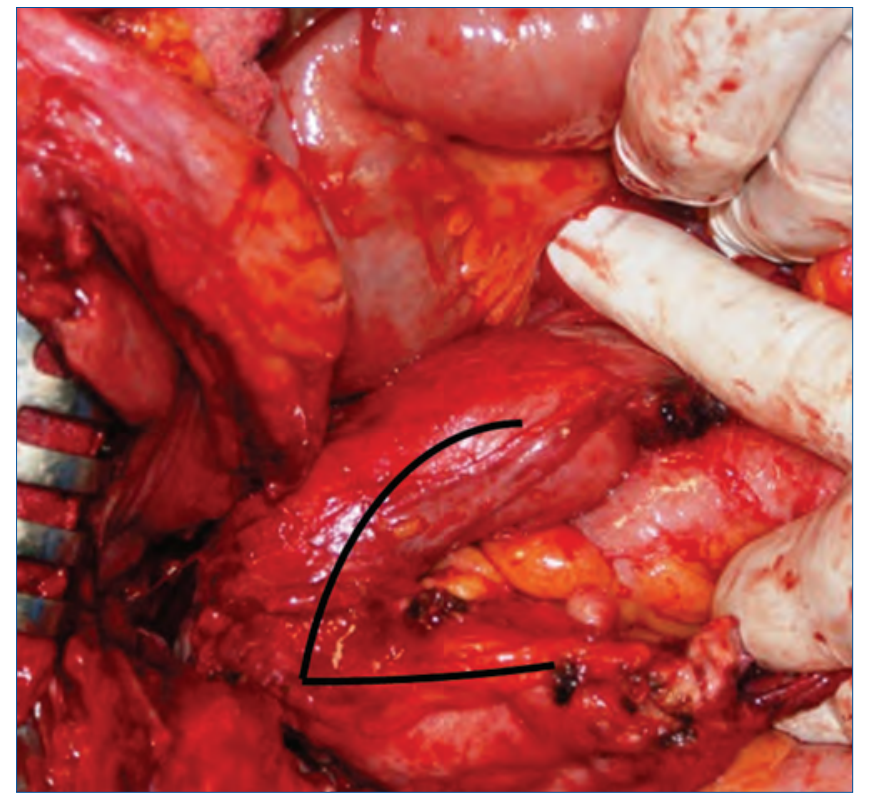

2. ÁBRA: INTRAOPERATÍV FÉNYKÉP A KÉTSZARVÚ, FEKETE VONALLAL JELÖLT MÉHRŐL ELTÁVOLÍTÁS ELŐTT

nopauza előjeleként a menstruáció rendszertelenné, de annál fájdalmasabbá vált. 2014-ben ismételt MRvizsgálattal tisztáztuk az utolsó mütét óta kialakult új anatómiai helyzetet. Tekintve, hogy a beteg a gyerekszülésről letett, így nőgyógyásszal konzultálva a legjobb megoldásnak a maradék hólyag és a kétszarvú uterus eltávolítását tekintettük (2. ábra). Az eltávolításon kívül fontos cél volt még a Tuffier-fisztula bezárása a rectum felé, ezt colostoma védelmében, két rétegben varrtuk meg. A féléves várakozás után a colostomát zártuk, és a korábbi fájdalom, lázas epizódok megszüntek (3. ábra). Bár a vizeletes sztóma jól müködött, 2015-ben a kreatininszint lassan újra emelkedni kezdett, amely konzervatív kezelésre diuretikum, diéta, folyadékbevitel-növelés - elöször jól reagált. Három évvel a Bricker-hólyag képzése után jól van, de látszik, hogy később valószínüleg müvesekezelésre fog szorulni.

\section{Megbeszélés}

Az összetett hólyag fejlődési rendellenességek előfordulása az elmúlt 10 évben jelentősen csökkent a terhesség alatti genetikai szúrővizsgálatoknak köszönhetően, de más országból érkezett

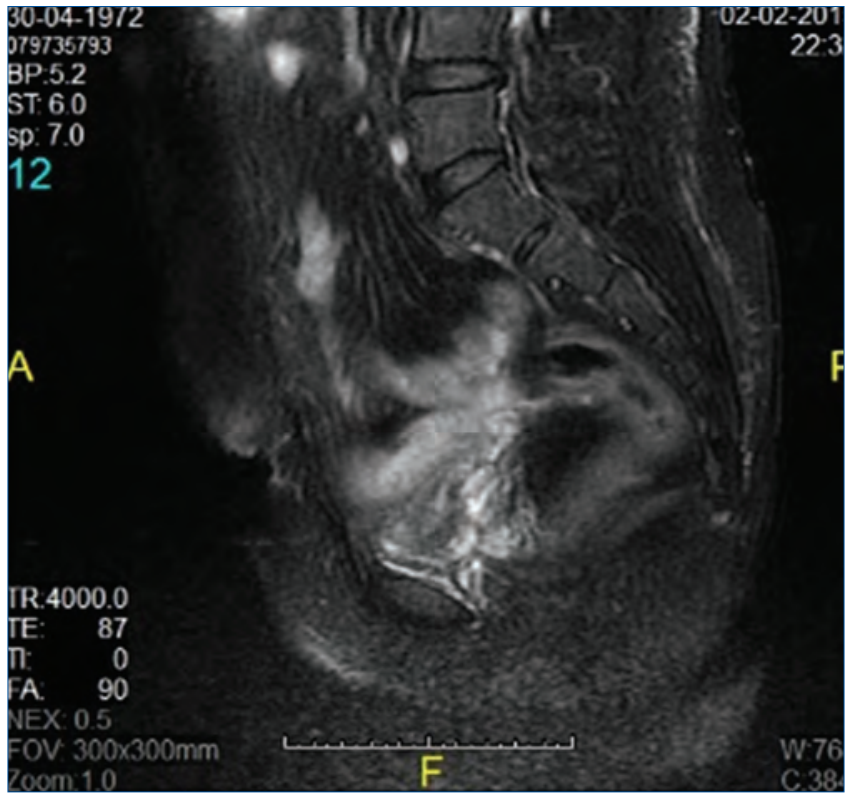

3. ÁBRA: ELLENŐRZŐ MR-FELVÉTEL, A FISZTULA MEG= SZÜNT, A ZSUGORHÓLYAG ÉS AZ UTERUS NEM LÁTSZIK

esetek még előfordulnak. A teljes rekonstrukció csak szerencsés esetben sikerül, gyakran mútétsorozatok árán. A cél azonban világos; a vesék kímélése, a hólyag tárolási és ürítési feladatának helyreállítása, a kontinencia megórzése. Részleges, de hosszú távon is jó megoldás a vizeletes sztómaképzés, erról azonban a betegek, még inkább a szülők idegenkednek.

Tökéletes megoldás sajnos nem létezik, ha azonban a legkisebb lehetőség megmarad a széklet-vizelet-keveredés megakadályozására, akkor azt érdemes kihasználni. A Tuffier-fisztula szerepet játszott a kialakult veseelégtelenség keletkezésében, ezen kívül a nem múködő hólyag a benne pangó széklet-vizelet-keverék miatt alhasi fájdalmat, és lázas állapotokat tartott fenn. A gyermekkori mútétek késői szövődményeit a felnőttkori mútétekkel csak részben sikerült elhárítani, a panaszok megszúntek, a szérum kreatininemelkedés lelassult, de visszafordítani nem lehetett. Az appendixben talált és eltávolított endometriózisnak a megfigyelt időperiódusában jelét nem észleltük, így ilyen irányú további vizsgálatokat nem végeztünk, kezelést erre a beteg nem kapott. A Tuffier-sipoly készítése régi, elavult mútét, késői következményei előre láthatók. Ezek megszüntetése azonban a mai urológusok feladata. A szövődmények hasonlítanak az uretero-sigmoidostomia következményeihez és megszüntetésük bonyolult mútéti sorozattal lehetséges, ez pedig kihívást jelent a kezelőorvosoknak.

\section{Irodalom}

1. Pajor L, Romics I. Modified ureterosigmoidostomy (Mainz II) technique and early results. BJU 1999; 84 (1): 157.

2. Szücs M, Keszthelyi A, Szendrői A, Dombóvári P, Majoros A, et al. Investigation of anal sphincter function following Mainz pouch type II urinary diversion after radical cystectomy. Int Urol Nephrol 2012; 44: 1013-1020. https://doi.org/10.1007/s11255-012-0142-z

3. Wallace A. Tuffier fistula. Proceedings of Royal Society of Medicine, Section of Urology Papers 1961 May; 54: 383. 